\title{
Conceptualizing The Floating Court Based On E-Floating Court To Realizing Public Service The Justice System In The Fourth Industrial Revolution Era
}

\author{
Juan Maulana Alfedo, Laras Ayu Lintang Sari, Emilda \\ Yofita \\ 1Faculty of Law, Brawijaya University, ${ }^{2}$ Faculty of Law, Brawijaya University, ${ }^{3}$ Faculty of Law, \\ Brawijaya University \\ Jl. M.T. Haryono 168 Kota Malang, Jawa Timur 65145
}

Article Info: Submitted February 24, 2020 Accepted April 26, 2020

Published May 9, 2020

\begin{abstract}
s :
Indonesia is the biggest archipelago in the world with area of 5.9 million $\mathrm{km}^{2}$ with 6.4 million tons of fisheries resources. But with this potential there are still many crimes at sea; one of them is illegal fishing. To overcome various crimes at sea, the government provides the Shipping Court and the Fisheries Court which are expected to fulfill the legal needs of the sea, but in their implementation the two institutions are less than optimal. In the industrial revolution era 4.0, need a means to optimize public services in the justice system, especially in the maritime area. Based on the problem, we established the floating court based on e-floating court which is judicial institution to synergize the performance of shipping court and fisheries court in enforcement of marine law in Indonesia. In this study the authors used a juridical-normative research method.
\end{abstract}

Keyword: E-Floating Court, Floating Court Justice System, Industrial Revolution Era 4.0

\begin{abstract}
Abstrak:
Indonesia adalah Negara kepulauan terbesar dengan luas wilayah laut 5,9 juta $\mathrm{km} 2$ dengan 6,4 juta ton sumber daya perikanan. Dengan potensi berlimpah tersebut masih terjadi pelanggaran, salah satunya kasus Illegal Fishing. Pemerintah menyediakan Mahkamah Pelayaran dan Pengadilan Perikanan yang diharapkan mampu memenuhi kebutuhan hukum di laut, namun dalam implementasinya kedua lembaga tersebut kurang optimal. Di era revolusi industri 4.0, diperlukan sarana untuk mengoptimalkan layanan publik dalam sistem peradilan, terutama di bidang kelautan. Berdasarkan hal tersebut penulis membentuk pengadilan apung berbasis e-floating court guna mensinergikan peran lembaga tersebut untuk menegakkan hukum laut di Indonesia. Dalam Penelitian ini menggunakan metode yuridis-normatif Kata Kunci : E-Floating Court, Floating Court, Justice System, Industrial Revolution Era 4.0
\end{abstract}

\section{Citation :}

Alfedo, J.M, Sari, L.A.L, Yofita, M. (2020). Conceptualization the Floating Court Based on E-Floating Court to Realizing Public Service the Justice System in The Fourth Industrial Revolution Era, Lex Scientia Law Review, 4(1), 119-132, doi : https://doi.org/10.15294/lesrev.v4i1.37732 


\section{Preliminary}

Indonesia is the biggest archipelago state in the world. This is proven by calculations based on the United Nations sea law Convention on the Law of the Sea (UNCLOS) which was implemented in 1982, which after calculating the total area of Indonesia's sea area reached 5.9 million $\mathrm{km} 2$, excluding the take-off continent (continental shelf). The area covers 3.2 million $\mathrm{km} 2$ territorial waters and 2.7 million km2 waters Exclusive Economic Zone ${ }^{1}$. The exclusive economic zone, which counts from 12 to 200 miles from the coastline of the outermost point of the archipelago, is a zone that cannot be forgotten, because in this zone Indonesia still has sovereign rights, there are the right to manage and use marine resources.

As stipulated in Article 25A of the 1945 Constitution of the Republic of Indonesia, it states that "The Unitary State of the Republic of Indonesia is an archipelagic country characterized by an archipelago with territories whose boundaries and rights are determined by law". This further confirms the existence of Indonesia as a maritime country and recognizes the existence of the marine and fisheries sector and the management of coastal areas. Comparison of Indonesia's sea area which is greater than the land area causes Indonesia to have a large natural resource potential of marine products.

The great potential of Indonesia's maritime becomes a serious threat if security in maritime affairs has not been maximized ${ }^{2}$, this is due to the ability of supervision especially the national surveillance fleet (surveillance vessels) is still very limited compared to the need to monitor vulnerable areas. Illegal fish theft or illegal fishing is a fishing activity ${ }^{3}$ :

a. Which is carried out by a foreign person or ship in a water which becomes the jurisdiction of a country without the permission of that country or contrary to applicable laws and regulations.

b. Which is contrary to applicable national regulations or international obligations.

Problems for illegal fishing who cross the national sovereignty will be punished according to the country's rules, and regulated in accordance with UNCLOS law article 49 of 1982 which explains the boundaries that cannot be violated by foreign fishermen, because it is written clearly in the article the legal status of the archipelago waters, air space above the archipelago waters and the seabed and the land beneath it is the sovereignty limit of the state, so that if foreign fishermen who pass through the sovereignty of the country and take action of stealing fish, then it can be confirmed as illegal fishing.

The impact of illegal fishing that occurred so far is most felt by Indonesian fishermen; this is because the fishermen use the wealth of the sea to catch fish and others. In addition, due to the rise of illegal fishing practices, the activities of fishermen in fishing in the sea are hampered so that the results can not be in accordance with their daily needs. This foreign fisherman who conducts illegal fishing catches fish in

\footnotetext{
${ }^{1}$ Lasabudi, R. (2013). Pembangunan Wilayah Pesisir dan Lautan Dalam Perspektif Negara Kepulauan Republik Indonesia. Jurnal Ilmiah Platax, 1(2). P. 45

${ }^{2}$ Ambarwati, R. (2014, October 8). Membangun Kelautan Untuk Mengembalikan Kejayaan Negara. Retrieved from: http://www.ppk-kp3k.kkp.go.id/ver2/news/read/115/membangun-kelautan-untukmengembalikan-kejayaan-sebagai-negara-maritim.html, Accessed on April 192020.

${ }^{3}$ Dinas Perikanan dan Kelautan Kabupaten Langkat. (2016). Apa yang dimaksud IUU Fishing. Retrieved from: http://diskanla.langkatkab.go.id/berita/berita-nasional/59-apa-yang-dimaksud-iuu-fishing- .html , Accessed on April 192020.
} 
the Indonesian sea on a large scale in a way that can damage fish habitat such as fishing using bombs, poisons, and various prohibited fishing gear that violates the provisions of existing laws. This causes huge losses for the country and especially Indonesian fishermen who depends their lives on the sea.

One case of illegal fishing that is detrimental to society and the country is the case of a Vietnamese ship that stole $500 \mathrm{~kg}$ of fish caught in the waters of the South Natuna Sea. Natuna is considered to have the diversity of natural resources contained therein which is very potential for the economic development of a country, and therefore many foreign fishermen did the illegal fishing in Natuna. The arrest occurred when Indonesian Navy personnel were patrolling and found a suspicious Vietnamese ship crossing at position $04^{\circ} 50$ '87 "U-105 ${ }^{\circ} 25^{\prime} 70^{\prime \prime} \mathrm{T}$, precisely in west Natuna Sea at the end of 2018. Following this up, the KRI Teuku Umar-385 carried out procedures for chasing, arrest, and investigation, followed by the role of inspection and search of cargo, personnel and documents of the ship. From the investigation it is known as KG91989TS Ship, Nationality of Vietnam and has been filled with many fish species.

Problems that cause illegal fishing in Indonesian waters are inseparable from the global strategic conditions, especially the condition of fisheries in other countries that have sea borders, and the fisheries management system in Indonesia itself ${ }^{4}$. The Barhakam Police and Water Police Directorate found 952 cases in Indonesian waters from January to November 2018. The most cases were illegal fishing. Not only illegal, Unreported and Unregulated (IUU) Fishing, but there are also various types of criminal acts such as smuggling goods from the sea, drug smuggling, Human Trafficking or human smuggling, terrorism, sea piracy, and other criminal acts that occur in the sea.

Sometimes Indonesian marine law is not matched by the application of clear sanctions and law enforcement, that caused many cases of theft and the re-release of the perpetrators of theft often occur. In addition, to overcome the problems that occur at sea, especially the issue of defense and security of marine resources, the government created Shipping Court that is under the scope of the Ministry of Transportation ${ }^{5}$. According to The Act Number 31 of 2004 concerning Shipping in the field of government justice also makes the Fisheries Court within the General Courts. The Shipping Court was formed by Decree of the Minister of Transportation No. KM 15 of 1999 concerning the Organization and Work Procedure of the Shipping Court while the Fisheries Court was formed by The Act Number 31 of 2004 concerning Fisheries which was later amended by The Act Number 45 of 2009 concerning amendments to the Act Number 31 of 2004 concerning Fisheries.

However, the roles of the Shipping Court and Fisheries Court are considered to be less than optimal even though the formulation in the law is quite clear and firm. The position of the Sailing Court is only in Jakarta as Capital City, even though its legal territory covers all regions in Indonesia, thus affecting the number of obstacles that arise in the handling of cases which become its competence. In addition, the jurisdiction and competence of the Court of Shipping are very limited to only provide disciplinary action, for example handling the problem of ship accidents ${ }^{6}$. Meanwhile,

\footnotetext{
4 Maulana, F. Permasalahan Illegal Fishing di Indonesia. Retrieved from: http://eprints.umm.ac.id/36161/3/jiptummpp-gdl-fuadmaulan-49045-3-babii.pdf , Accessed on 19 April 2020.

5 The Act Number 17 of 2008 Concerning Shipping

${ }^{6}$ BPHN Depkumham RI. (2005). Laporan Akhir Tim Analisis Evaluasi Peraturan Perundang-Undang tentang Yurisdiksi dan Kompetensi Mahkamah Pelayaran. BPHN Depkumham RI, Jakarta.
} 
the Fisheries Court considered Indonesia to cause many problems because the lack of consolidation of regulations in the marine law enforcement system led to the devising of jurisdiction. In addition, the number of judges in the Fisheries Court and those who control the law of the sea is still relatively small. The reduce of the fisheries court's essence itself

As the development of technology and information in the industrial revolution era 4.0, we need to optimize public services in the justice system, especially in the maritime area. There is still a lack of technology-based public services in the field of justice in Indonesia, even though the use of information technology in public services will facilitate the community concerned to complete administration in a court. Based on these problems, authors form a floating court design based on e-floating court which is a special court to synergize the performance of the Shipping Court and Fisheries Court in the enforcement of marine law in Indonesia and facilitate public services because it uses technology and information as one form of development of industrial revolution 4.0.

\section{Problem Formulation:}

1. What is the problem with public services in the current maritime sector justice system

2. How is the conceptualization of the floating court based on e-floating court in order to realize public services in a justice system in the era of the industrial revolution 4.0 ?

\section{Purpose}

1. To find out the problems of public services in the current maritime sector justice system.

2. To find out and describe the conceptualization of the floating court based on efloating court in order to realize public services in the justice system in the era of the industrial revolution 4.0.

\section{Research Methods}

\section{A. Research Approach}

This type of research is normative juridical or also called doctrinal law research, that is, researchers examine secondary legal material 7 , then proceed with research on primary data in the field to address problems that are the focus of research that conceptualizes law as a rule or norm which is the benchmark behave human beings deemed appropriate. The approach method used in this research is:

1. The statute-approach is by examining the statutory regulations ${ }^{8}$, relating to the Special Court and Electronic Justice System.

2. Conceptual approach (conceptual approach) is by examining and understanding the concepts 9 Public Services, Maritime Zone, and Theory of Justice.

3. Case approach is by conducting a review of cases relating to the legal issues at hand.

The types of legal material used in this study consisted of:

\footnotetext{
${ }^{7}$ Soemitro, R.H. (1988). Metodologi Penelitian Hukum dan Jurimetri. Jakarta : Ghalia.

${ }^{8}$ Marzuki, P.M.(2007). Penelitian Hukum. Jakarta : Kencana.

${ }^{9}$ Ibrahim, J. (2007). Teori dan Metodologi Penelitian Hukum Normatif. Malang : Bayumedia.
} 
1. Primary Legal Materials are legislation includes.

a) The 1945 Constitution of the Republic of Indonesia;

b) The Act Number 25 of 2009 Concerning Public Services.

c) The Act Number 17 of 2008 Concerning Shipping.

d) The Act Number 31 of 2004 Concerning Fisheries.

e) The Act Number 3 of 2002 Concerning National Defense.

f) The Act Number 23 of 2019 Concerning Management of National Resources for National Defense.

g) The Republic of Indonesia Supreme Court Regulation Number 3 of 2018 Concerning Electronic Case Administration in Courts.

h) United Nations Convention on the Law of the Sea (UNCLOS) 1833.

2. Secondary Legal Materials include books or literature, journals, research results as well as works from scholars and legal experts as well as other written or qualitative sources.

3. Tertiary Legal Materials include a legal dictionary.

\section{B. Legal Search Techniques}

The technique of tracing legal materials in this research was carried out through documentation studies and literature studies, as well as from the internet. To get the required legal material, the writer traces the legal material in the Legal Documentation and Information Center of the University's Faculty of Law, University Central Library and Public Library and City Archives.

\section{Legal Materials Analysis Techniques}

All legal materials that have been collected are then inventoried, classified and analyzed using descriptive analysis that aims to describe various existing legal problems, so that an appropriate solution is obtained, in order to provide new concepts through the Floating Court based on e-floating court in realizing public services in justice system in the industrial revolution era 4.0. Descriptive method, which is a method used to study problems that exist in society, as well as procedures that apply in everyday society and certain situations ${ }^{10}$. The purpose of this descriptive writing is to make a systematic, factual and accurate picture of the facts, the characteristics, and the relationship between the phenomena carefully to get a solution. After the analysis process, the synthesis process is carried out by attracting and linking the formulation of the problem, the purpose of the writing as well as the discussion conducted. Next, general conclusions are drawn based on legal material obtained in the research that is written concisely and contains enough information with the aim of knowing the main ideas or ideas that can be taken, then recommended several things as an effort to transfer ideas for further research.

\section{Result and Discussion}

${ }^{10}$ Nazir, M. (2005). Metode Penelitian. Jakarta : Ghalia. 
Law enforcement is a process to describe values, ideas, to have concrete goals and contain moral values such as, justice and truth. These values can be realized in reality ${ }^{11}$. Through law enforcement, there will be restrictions on those directly involved in the field of law enforcement, include those who work in the fields of justice, prosecutors, police, and penitentiary. The Lack of consolidation of regulations in the marine law enforcement system results in the discoordination of jurisdiction which results in the suboptimal execution of cases that go to court. In terms of licensing services in the fisheries sector is considered slow and $90 \%$ of small-scale fisheries business operators still have difficulty accessing business financing, both from banks and non-donors ${ }^{12}$. The condition of law enforcement for the fisheries sector is also relatively low, both in quantity and quality. The lack of law enforcement in the field of fisheries, besides causing state losses both economically and environmentally also has an impact on the enforcement of the country's territorial sovereignty, resulting in the Indonesian people becoming sovereign in their own country (Ministry of National Development Planning Agency)

Problems with national sea law enforcement in Indonesia need to be photographed and mapped. This aims to make it easier for policy makers to find solutions. According to the Chief Technical Advisor of the European Union-United Nations Development Program, Gilles Blanchi, there was a significant difference between the number of illegal criminal cases, reported by the media and the number of cases that reached the court. Furthermore, below, the authors present a summary of data handling cases of fisheries criminal offenses that occur in the exclusive economic zone of Indonesia:

Table 2. Recapitulation of data handling fisheries criminals' acts that occur in the ZEE in 2015-2018

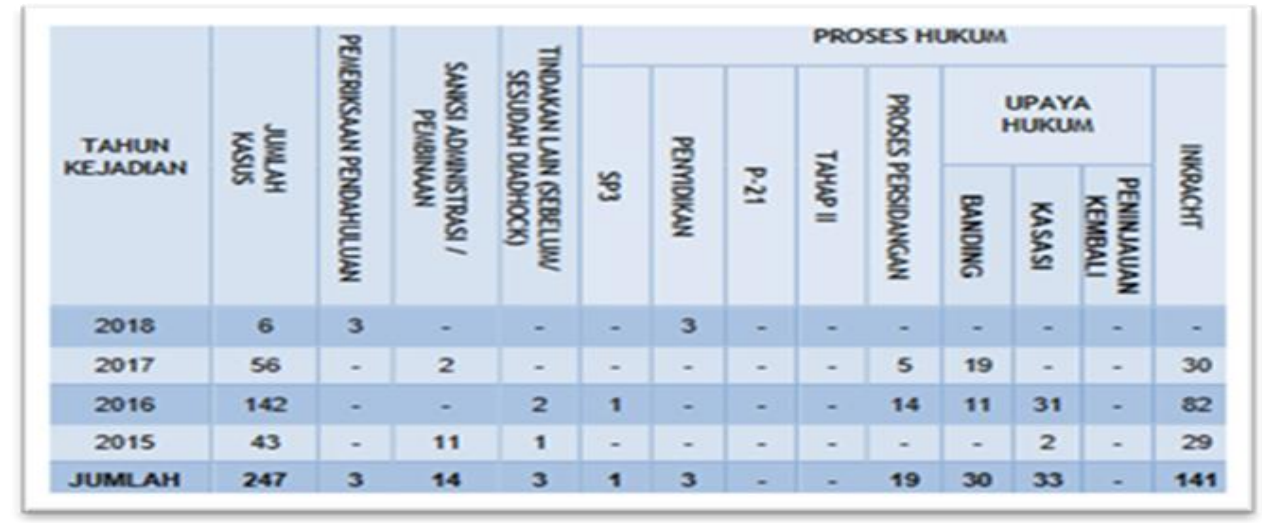

Source: Directorate of Violation Management

Some of the problems of national sea law enforcement in Indonesia include:

1. Law enforcement is carried out in a discriminatory manner. So far, sanctions in the form of punishment are more often imposed on law violators of the lower middle class, while law violators who are classified as middle and above are impossible to be touched by severe sanctions. As the first example, the emergence of the Maluku

\footnotetext{
${ }^{11}$ Rahardjo, S.( 2009). Pengetahuan Hukum: Suatu Tinjauan Sosiologis. Yogyakarta : Genta.

12 Anonymous. (2017, September 24). Wujudkan Poros Mairitm Dunia Pelayanan Publik Kelautan dan Perikanan Harus Ditingkatkan, from: https://economy.okezone.com/read/2017/09/24/320/1781992/wujudkan-poros-maritim-dunia-pelayananpublik-kelautan-dan-perikanan-harus-ditingkatkan, Accessed on April 192020.
} 
High Court decision strengthens the fisheries court ruling in the Ambon District Court. In the decision that has permanent legal force, Zhu Nian Le, the ship's captain, was only rewarded with a fine of IDR 200 million subside 6 months in captivity. Second, the fisheries court at the Ambon district court only fined IDR 100 million of the five PT Sino vessels that were clearly involved in illegal fishing in Indonesian waters, and 3 of them did not have a fishing license. However, if viewed from a normative perspective, in Article 93 paragraph 1 of the Fisheries Law, violators can be sentenced to a maximum of 6 years and a maximum fine of IDR 2 billion ${ }^{13}$.

2. The management of handling legal cases is still not effective and efficient. The length of cases handled can make the parties concerned feel disadvantaged by the actions of law enforcement officials ${ }^{14}$. Seeing the above facts it is necessary to reform the Indonesian sea law. Some factors that affect law enforcement and need to be addressed are:

a) The legal factor itself is overlapping regulations or norm conflicts between the fisheries, shipping, criminal code and criminal code procedures laws as well as several additional regulations.

b) Law enforcement factors are those who form and implement the law. Lack of coordination and soft skills of law enforcement apparatuses related to national sea law.

c) Factors of facilities or facilities that support law enforcement. The author focuses on the judiciary as an institution that has a role in law enforcement that manages all marine law issues for citizens who experience these legal problems. As stated by Jeremo Frank, the main objective of making justice institutions more responsive to social needs is nothing but achievement to encourage improvement of public services themselves ${ }^{15}$

B. Conceptualization of Floating Courts Based on e-Floating Courts in order to realize public services in the justice system in the Industrial Revolution Era 4.0.

One of important factor in safeguarding marine resources is the process of law enforcement. Law enforcement becomes a necessity to overcome various problems in the maritime sector. Law enforcement in the maritime sector must be supported by adequate legal instruments and the support of good justice institutions. Therefore we need a specialized judicial institution that is more professional and able to answer various legal issues in the maritime sector ${ }^{16}$. The Floating Court is the answer to the powerlessness of the existing justice institutions in resolving various violations of the

\footnotetext{
${ }^{13}$ Sukmana, Y. (2015, September 14). Kecewa Berat Menteri Susi Minta Pemerintah Tutup Pengadilan Perikanan Ambon, Retrieved from: https://money.kompas.com/read/2015/09/14/160246826/Kecewa.Berat.Menteri.Susi.Minta.Pemerintah.T utup.Pengadilan.Perikanan.Ambon/, Accessed on April 192020

${ }^{14}$ Sawitri, A.A. ( 19, April 2016) Tidak Banyak Kasus Pencurian Ikan Masuk Pengadilan. Tempo.co. Retrieved from https://nasional.tempo.co/read/763809/undp-tidak-banyak-kasus-pencurian-ikan-masukpengadilan, Accessed on April 192020.

${ }^{15}$ Nonet, P, Selzik, P. (2017). Hukum Responsif. Bandung : Nusamedia.

${ }^{16}$ Asshidique, J. (2013). Pengadilan Khusus dalam Bunga Rampai Putih Hitam Pengadilan Khusus. Jakarta : Komisi Yudisial RI.
} 
law in the maritime sector. The Floating Court is a special court under the supervision of the Supreme Court which has the authority to examine and prosecute offenses in the maritime field.

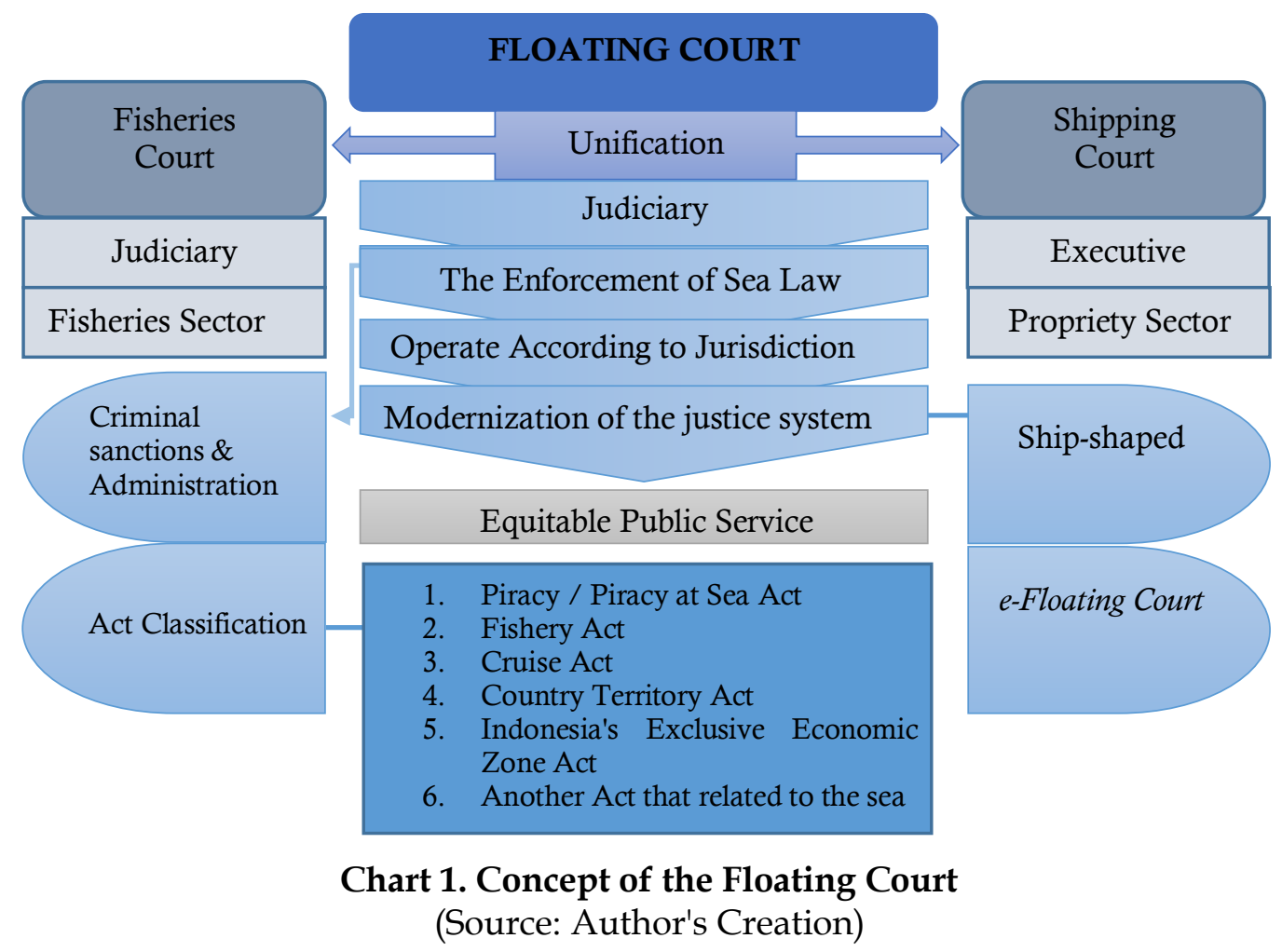

In addition, the Floating Court is also authorized to examine and prosecute violations of the shipping code of ethics conducted by the Captain and Ship Officers in the field of shipping such as (1) Driving a ship and causing a collision with other ships; (2) Give orders to the crew to carry out crimes; (3) Making decisions in ships with despair so that sea vessels are ignored; (4) Taking responsibility for driving a ship, while the special certificate for driving a ship does not have. (5). Take part in robbery on a ship or commit a crime of pirates; (6) Hijacking the ship that is being driven; (7) Disregarding the rules of sea crossing signs by sea guards. (8) Imposing ships that run when anchored without permission from Syahbandar; (9) Making the ownership rights of the cargoes inside the ship the property of the skipper; (10) The master neglects and leaves the ship without the permission of the ship owner.

For violations that are criminal in nature, the floating court has the authority to impose criminal sanctions on the defendant, whereas for violations that violate the code of ethics, administrative sanctions will be imposed. The delik classification which becomes the authority of the floating court includes ${ }^{17}$ :

1. Criminal offense piracy / piracy at sea is an act of seizure or illegal detention, or destroying a person or property, which is carried out by the crew or passengers of a ship.

2. Fisheries offenses are illegal fishing activities as regulated and threatened with criminal sanctions by the fisheries law.

\footnotetext{
17 Setiawan, I. (2016). Beragam Tindak Pidana Laut dalam Hukum Pidana Indonesia. Jurnal Unigal, 1.P. 119
} 
3. Shipping Delic is all acts of violation of everything related to transportation on the voyage, to the port, as well as security and safety in the shipping field.

4. State territory act is the actions of foreign vessels that deliberately sail or float for certain purposes which have an influence on security and / or through a closed area in the territorial waters of Indonesia without permission.

5. Indonesia Exclusive Economic Zone (ZEE) act is the act of entering the territory of Indonesia's exclusive economic zone without a permit that can cause material losses.

6. Another offense by sea

The Floating Court is the result of a fusion between the Fisheries Court and the Sailing Court so that it creates the effectiveness of the justice system in the context of enforcing marine law. But the Floating Court is not only the fusion of the two institutions but also as an effort to improve and overcome various obstacles that hit the Fisheries and Shipping Courts collectively. Improvement efforts in terms of the Fisheries Court are focused on the Floating Court and issues related to the competence of the substance of law enforcement are carried out with a recruitment system that emphasizes quality standards. In terms of the Shipping Court, the improvement made is the ability to impose administrative sanctions. Seeing the Floating Court which merges and develops the authority of the two bodies, it is also automatically necessary to increase the number of law enforcement personnel. The Floating Court recruitment system is carried out by utilizing existing career judges to be fostered specifically to deal with offenses in the maritime sector that has been conducted so far (certification). In addition, marine justice education can be carried out for sea law practitioners in order to obtain a judge's certificate as an effort to set the floating court quality standards. The recruitment system and efforts to establish quality standards are carried out to guarantee the justice system by following the guidelines of the legal norms as well as possible in order to achieve material justice. But the Floating Court is not only focused on justice based on the law but also on moral and social justice.

As a form of modification of the justice system, the floating court concept is realized in the form of ships that will operate around the sea in accordance with their jurisdiction. The Floating Court will later be located in every province that has sea territory, so as to realize efficiency if there are violations that occur at sea. The Grand Design of the Floating Court. 

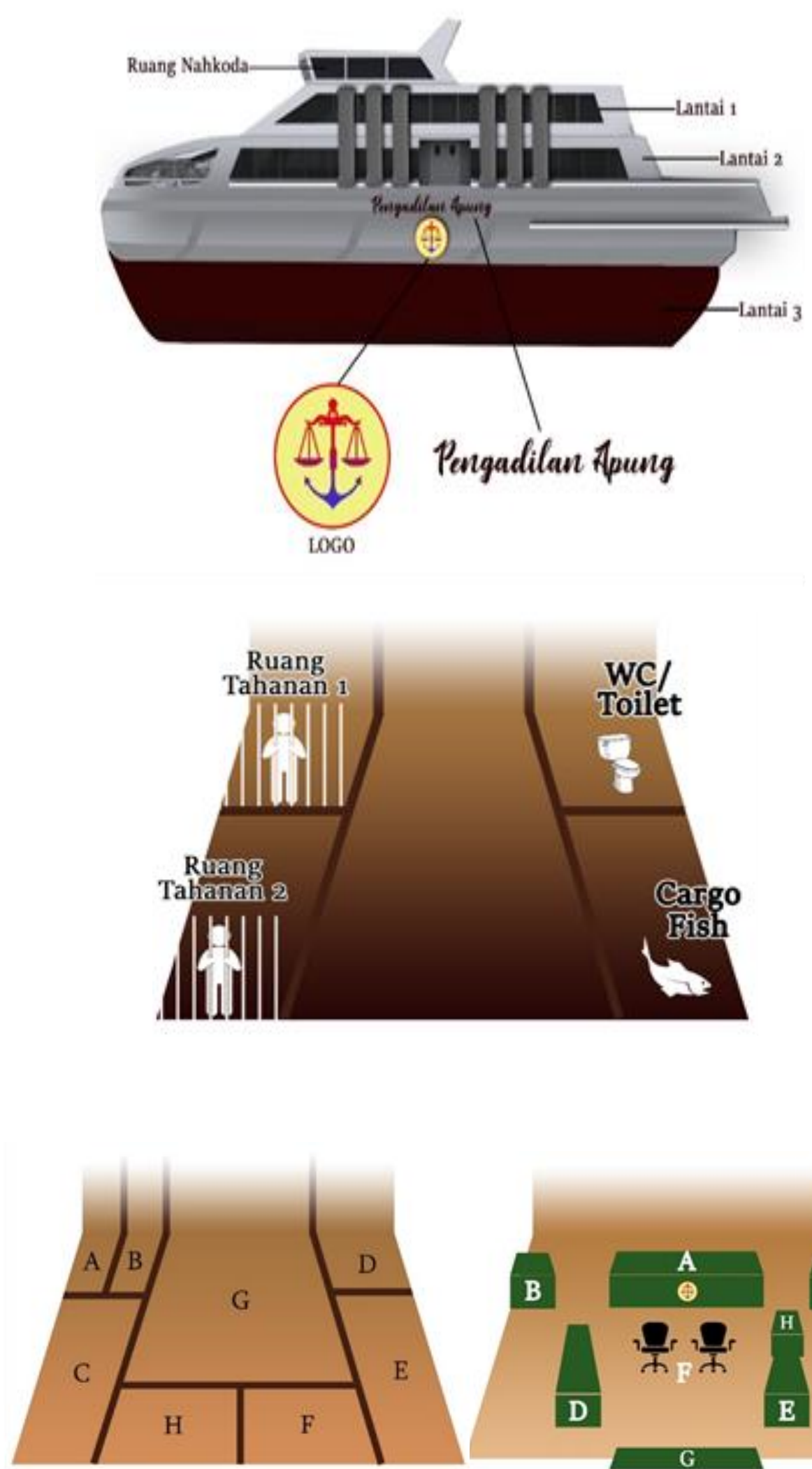

A= Ruang Jaksa

$E=$ Ruang Keskretariatan

B= Ruang Mediasi

F= Ruang Polisi

$G=$ Ruang Tunggu Pengunjung $\mathrm{H}=$ Ruang Istirahat

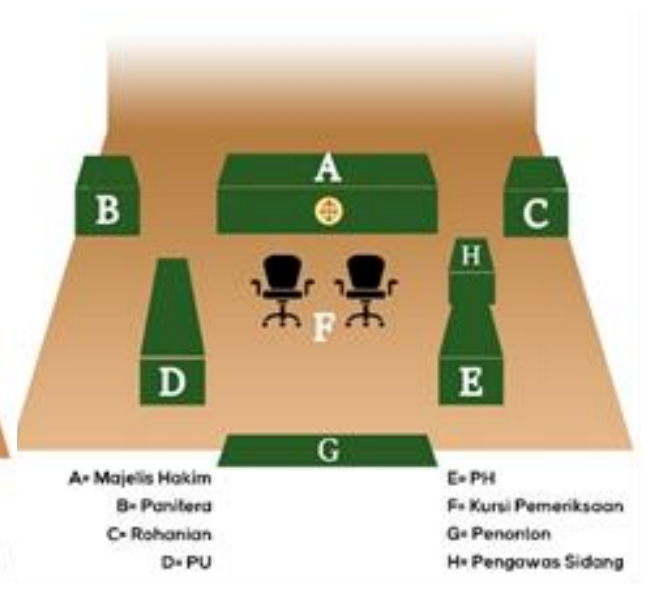

The Floating Court consists of three floors with rooms that have different

https://journal.unnes.ac.id/sju/index.php/lslr/ 
functions including:

1. The First Floor is a courtroom used for the judicial process in examining, adjudicating, and deciding cases in the maritime sector. To guarantee legal certainty, both at the level of investigation, prosecution, and examination at a court hearing, the Floating Court uses the procedural law to be faster.

2. The second floor is an operational room consisting of the Prosecutor's Room, Mediation Room, Registrar's Room, Evidence Room, Secretariat Room, Police Room, Visitor Waiting Room, and Rest Room.

3. Third floor, consisting of Detention Room, Water Closet, and Cargo Fish. The detention room is designed on the bottom floor and at the same time in the Floating Court with the aim of providing psychological treatment to the perpetrators to have a deterrent effect. This is also done solely so that the law can always provide drugs (Lex Semper Dabit Remedium) for criminals.

Along with the development of technology and information in the industrial revolution era 4.0, we need a means to address the problem of the lack of public services in the justice system in the maritime sector in order to resolve various violations that threaten national sovereignty and interests. Therefore, as a form of court modernization following the development of the industrial revolution era 4.0, the floating court in order to realize public services in a justice system that is fair to the community, will use a service mechanism based on e-floating court that makes it easy for litigants without having to come to court. e-floating court is an electronic-based Floating Court service in filing a lawsuit to the Court. The scope of e-floating court in the Floating Court includes:

1. E-Filling (e-filling of cases at the court) e-filling is used for the registration of case registrations while simultaneously submitting case files online. The results of data entry will be verified and will be processed procedurally.

2. E-Skum (Online Fee Estimated Estimated) after registering a case online the registrant will get an estimated online fee and payment number.

3. E-Payment (Online Case Payment Down Payment) e-payment can be used to make payment of the down-payment of court fees online as a follow-up to online registration.

4. E-Summons (Online Party Calling) As stipulated in Article 11 of the Republic of Indonesia Supreme Court Regulation Number 3 of 2018 concerning Case Administration in Electronic Courts, that "other than as stipulated in procedural law, summons to attend court proceedings against litigants can be delivered electronically". The legality of electronic calls is a valid and proper call, as long as the call is sent to the electronic domicile within the grace period determined by law 18

5. E-Litigation (Online Trial) e-Litigation is used for sending trial documents such as replicas, duplicates, answers, conclusions, and decisions electronically.E-floating court is the application of the principle of simple, fast and light in the justice

${ }^{18}$ The Supreme Court Regulation of Republic Indonesia Number 3 of 2018 concerning Case Administration at Courts Electronically 
system while expediting the administration process and public services in the justice system that is fair and guarantees the delivery of public services based on legal certainty as stipulated in Article 4 letter b of The Act Number 25 of 2009 concerning Public Services. In addition, the floating court in the Floating Court is an effort to support the Supreme Court program:

"In pouring efforts to improve the realization of the Supreme Indonesian Judiciary, which one of the efforts is oriented to excellent public service, one of the missions that has been set is to provide justice to justice seekers. Therefore, it is imperative for every Indonesian judicial body to improve public services and provide guarantees for a fair trial process." 19

The e-floating court in the Floating Court is also in order to meet the increasing public demands for justice services in the era of the industrial revolution 4.0 and to open space for the public to be able to obtain excellent public services. At the level of implementation, the implementation of the Floating Court concept by the Indonesian state can be carried out in stages after it has a legal basis and a clear structure governed by the law. The concept of the Floating Court has several advantages, such as the implementation of a more integrated sea law because the judicial process of all maritime related matters is carried out directly by a judicial body so that it indirectly supports the implementation of marine activities in Indonesia so as to create harmonization of sea law in Indonesia.

\section{Conclusion}

Based on the description above, several conclusions can be drawn as follows:

1. Indonesia as a country rich in marine resources needs a strong, fair and strict law enforcement to protect national sea law. The judiciary that has the authority to enforce national sea law is the Court of Shipping and the Fisheries Court, but the existence of the institution is considered to be less effective even though its formulation in the law is quite clear and firm.

2. The Floating Court which is the result of a fusion between the Fisheries Court and the Sailing Court so as to cause the effectiveness of the justice system in the context of enforcing marine law. The Floating Court is a form of modernization of the justice system based on e-floating court in order to realize public services in a justice system that is fair in the industrial revolution era 4.0.

\section{Suggestion:}

The suggestions that can be given by the authors to related stakeholders are as follows:

1. The government is expected to immediately implement the concept of the Floating Court based on e-floating court as an effort to enforce national marine law and provide public services in the justice system in the maritime area.

2. It is expected that the House of Representatives of the Republic of Indonesia will immediately form laws relating to the Floating Court so that the implementation of the Floating Court has a clear legal basis and position in Indonesia's positive law.

\footnotetext{
${ }^{19}$ Nofriandi, P. (2017, August 28). Mahkamah Agung Republik Indonesia, Archieved from: https://www.mahkamahagung.go.id/id/berita/2688/kma-aparatur-peradilan-harus-melayani-dengansepenuh-hati Accessed on September 272019.
} 


\section{Acknowledgments}

The authors would like to thank profusely to the Faculty of Law, Universitas Brawijaya for helping to fund the research of the author so that it can be used as a reference by similar research. Do not forget we also thank the Faculty of Law, Semarang State University, which has published this article as one of the Lex Scientia journals. As well as that, we would like to thank our Law Faculty colleagues who have assisted in the implementation of this writing.

\section{References}

\section{Books:}

Asshidique, J. (2013). Pengadilan Khusus dalam Bunga Rampai Putih Hitam Pengadilan Khusus. Jakarta: Komisi Yudisial RI

BPHN Depkumham RI. (2005). Laporan Akhir Tim Analisis Evaluasi Peraturan Perundang-Undangan tentang Yurisdiksi dan Kompetensi Mahkamah Pelayaran. Jakarata: BPHN Depkumham RI

Ibrahim, J. (2007). Teori dan Metodologi Penelitian Hukum Normatif. Malang: Bayumedia

Marzuki, P.M. (2007). Penelitian Hukum. Jakarta: Kencana

Nazir, M. (2005). Metode Penelitian. Jakarta: Ghalia Indonesia

Nonet, P., Selzink, P. (2007). Hukum Responsif. Bandung: Nusamedia

Rahardjo, S. (2009). Pengetahuan Hukum: Suatu Tinjauan Sosiologis. Yogyakarta: Genta

Soemitro, A. (2016). Metodologi Penelitian Hukum dan Jurimetri. Jakarta: Ghalia

\section{Journals:}

Lasabuda, R. (2013). Pengembangan Wilayah Pesisir dan Lautan dalam Perspektif Negara Kesatuan Republik Indonesia, Jurnal Imiah Platex, 1(2), pg. 45

Setiawan, I. (2016). Beragam Tindak Pidana Laut dalam Hukum Pidana Indonesia. Jurnal Unigal, 1(2). pg.119

\section{Online/World Wide Web:}

Ambarwati, R. (2014, October 8). Membangun Kelautan untuk Mengenmbalikan Kejayaan Negara Maritim. Klikpositif.com. Retrieved from http://www.ppkkp3k.kkp.go.id/ver2/news/read/115/membangun-kelautan-untukmengembalikan-kejayaan-sebagai-negara-maritim.html, Accessed on September 192019

Anonymous. (2017, September 24). Wujudkan Poros Maritim Dunia Pelayanan Publik Kelautan dan Perikanan Harus Ditingkatkan. Retrived from https:/ / economy.okezone.com/read/2017/09/24/320/1781992/wujudkanporos-maritim-dunia-pelayanan-publik-kelautan-dan-perikanan-harusditingkatkan, Accessed on September 42019

Dinas Perikanan dan Kelautan Kabupaten Langkat. (2016). Apa yang dimaksud IUU Fishing. Retrived from http://diskanla.langkatkab.go.id/berita/beritanasional/59-apa-yang-dimaksud-iuu-fishing-html (Accessed on September 19, 2019)

Kementrian PPN/Bappenas. (2019, September 4). Isu Strategis dan Permasalahannya. Retrived from 
https://www.bappenas.go.id/files/9214/4401/4205/8_BAB_6_ISU_STRATE GIS_DAN_PERMASALAHANNYA.pdf, Accessed on September 5, 2019.

Maulana, F. (2017, February 23). Permasalahan Illegal Fishing di Indonesia. Retrived from http://eprints.umm.ac.id/36161/3/jiptummpp-gdl-fuadmaulan-490453-babii.pdf, Accessed on September 19, 2019.

Nofriandi, P. (2017, August 28). Mahkamah Agung Republik Indonesia. Retrived from https://www.mahkamahagung.go.id/id/berita/2688/kma-aparaturperadilan-harus-melayani-dengan-sepenuh-hati (Accessed on September 27, 2019)

Sawitri, A.A. (2016, April 19). Tidak Banyak Kasus Pencurian Ikan Masuk Pengadilan. Retrived from https://nasional.tempo.co/read/763809/undptidak-banyak-kasus-pencurian-ikan-masuk-pengadilan, Accessed on September 19, 2019.

Simanungkalit, A. (2014, Desember 12). Susi Giatkan Pengadilan Perikanan Tapi Begini Faktanya. Retrived from https://nasional.tempo.co/read/763809/undp-tidak-banyak-kasuspencurian-ikan-masuk-pengadilan, Accessed on September 172019.

Sukmana, Y. (2015, September 14). Kecewa berat Menteri Susi Minta Pemerintah Tutup Pengadilan Perikanan di Ambon. Retrived from https://money.kompas.com/read/2015/09/14/160246826/Kecewa.Berat.Me nteri.Susi.Minta.Pemerintah.Tutup.Pengadilan.Perikanan.Ambon/, Accessed on September 19, 2019.

\section{Laws and Regulations:}

The 1945 Constitution of The Republic Indonesia

The Act Number 17 of 2008 Concerning Shipping

The Act Number 25 of 2009 Concerning Public Service

The Act Number 31 of 2004 Concerning Fishery

The Supreme Court Regulation of The Republic Indonesia Number 3 of 2018 Concerning Case Administration at Courts Electronically 